\title{
Integralna obremenjenost prodnih ravnin Slovenije
}

\section{Drago Kladnik}

Mag., Geografski inštitut Antona Melika, Znanstvenoraziskovalni center SAZU, Gosposka ulica 13, 1000 Ljubljana, Slovenija e-mail: drago.kladnik@zrc-sazu.si

\section{Irena Rejec Brancelj}

Dr., Ministrstvo za okolje, prostor in energijo, Agencija RS za okolje, Vojkova ulica 1b, 1000 Ljubljana, Slovenija e-mail: irena.rejec-brancelj@gov.si

\section{Aleš Smrekar}

Mag., Geografski inštitut Antona Melika, Znanstvenoraziskovalni center SAZU, Gosposka ulica 13, 1000 Ljubljana, Slovenija

e-mail: ales.smrekar@zrc-sazu.si

\section{Izvleček}

Integralna obremenjenost prodnih ravnin v Sloveniji je rezultat prepletanja številnih dejavnosti na teh območjih, zato njeno preučevanje zahteva celosten pristop. Območja aluvialnih vodonosnikov v Sloveniji so ogrožena, kar je posledica naravne ranljivosti vodonosnikov in njihovih velikih obremenitev ter posledično slabe kakovosti podtalnice. Kaže se potreba po zaščiti kakovosti podtalnice.

Ključne besede: podtalnica, prodne ravnine, pitna voda, gnojišča in gnojne jame, vrtički, rastlinjaki

\section{Integral Burdening of Gravel Plains in Slovenia}

\section{Abstract}

The integral burdening of the gravel plains in Slovenia is the result of various interrelated activities in these areas, and its study therefore demands an integrated approach and the urgent protection of the groundwater quality. Areas of alluvial aquifers in Slovenia are threatened as the consequence of the natural vulnerability of aquifers, great burdening what is resulted in the poor quality of the groundwater.

Key words: groundwater, gravel plains, drinking water, dispersed sources, dunghills and dung pits, gardens, greenhouses 


\section{UVOD}

Podzemne vode so v Sloveniji najpomembnejši vir pitne vode. $Z$ njimi se oskrbuje več kot $90 \%$ prebivalstva. Za njegovo preskrbo s pitno vodo so najpomembnejši vodonosniki z medzrnsko poroznostjo $\mathrm{v}$ aluvialnih nanosih na ravninah. V Sloveniji spremljamo kakovost podzemnih voda v okviru državnega monitoringa že 15 let. Ves ta čas so bile v nekaterih aluvialnih vodonosnikih ugotovljene povišane vsebnosti določenih snovi, predvsem fitofarmacevtskih sredstev (FFS), nitratov in halogeniranih organskih spojin. V zadnjih letih se je kakovost podtalnice na splošno poslabšala.

Integralna obremenjenost prodnih ravnin v Sloveniji je rezultat prepletanja številnih dejavnosti na teh območjih in zato njeno preučevanje zahteva celosten pristop. Predstaviti želimo glavne vzroke za takšno stanje in nujnost ukrepanja. Podrobneje je predstavljena še problematika kmetijskih virov obremenjevanja na Ljubljanskem polju in znotraj avtocestnega obroča na območju Ljubljane.

Spoznanja o nujnosti zaščite kakovosti podzemnih voda so našla mesto tudi v novi slovenski zakonodaji. Tako je bila sprejeta Uredba o kakovosti podzemne vode (Ur. 1 .RS, 11/2002), ki navaja merila za določitev kemijskega stanja, čezmerne obremenjenosti podzemne vode ter merila za ugotavljanje njene ogroženosti. V uredbi so za posamezne parametre kemijskega stanja postavljene mejne vrednosti. Ugotovitve o čezmerni obremenjenosti podtalnice so bile podlaga najnovejše Uredbe o določanju statusa zaradi fitofarmacevtskih sredstev ogroženega območja vodonosnikov in njihovih hidrografskih zaledij in o ukrepih celovite sanacije (Ur. 1. RS, 77/2002) ter Odloka o območjih vodonosnikov in njihovih hidrografskih zaledij, ogroženih zaradi fitofamacevtskih sredstev (ibid.).

\section{INTEGRALNA OBREMENJENOST PRODNIH RAVNIN}

Na Agenciji Republike Slovenije za okolje so bile v letu 2002 pripravljene Strokovne podlage za razglasitev ogroženosti podzemne vode v Republiki Sloveniji (Rejec Brancelj in sod, 2002). Rezultati raziskav so pokazali, da so območja aluvialnih vodonosnikov v Sloveniji resno ogrožena. Ogroženost izhaja iz naravne ranljivosti vodonosnikov, velikih obremenitev in slabe kakovosti podtalnice. Ogroženost podzemnih voda je bila ocenjena za 13 aluvialnih vodonosnikov, za tiste, za katere je bilo mogoče določiti kemijsko stanje. Gre za aluvialne vodonosnike, na katerih poteka državni monitoring (karta). 


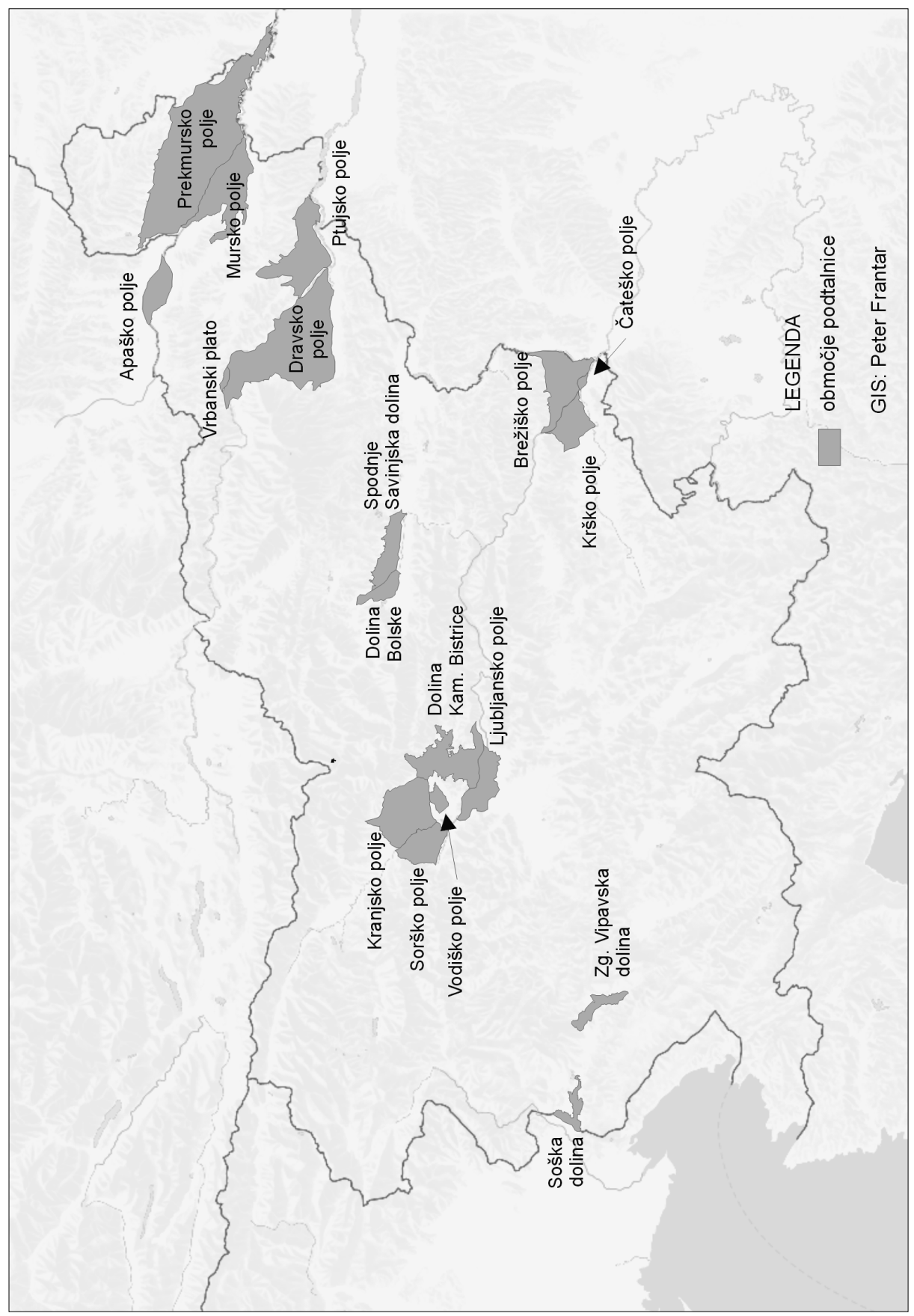

Karta 1: 
Za potrebe ocene ogroženosti podzemnih voda, ki je temeljila predvsem na rezultatih ocenjevanja kemijskega stanja podzemnih voda, je bila $v$ študiji podana ocena splošne ranljivosti vodonosnikov. Ocena temelji na hidrogeološki zgradbi in prepustnostnih sposobnostih posameznih litotipnih skupin, ob upoštevanju faktorja debeline nenasičene cone (Kranjc s sod., 1995). Celovita ocena naravne ranljivosti podzemnih voda pa bi terjala dodatno osvetlitev $\mathrm{z}$ naslednjimi kazalci: napajanje, topografija značilnosti tal, značilnosti nezasičene cone, hidravlična prevodnost, vrsta vodonosnika in globina do podzemne vode (Rejec Brancelj in sod, 2002). V prej omenjeni študiji je splošna ranljivost vodonosnikov razdeljena na pet stopenj, od katerih sta dve zastopani na opazovanih območjih. V razred zelo visoke ranljivosti (5) se uvrščajo kvartarni vodonosniki z zelo dobro prepustnostjo $\left(\mathrm{k}>5^{*} 10^{-3} \mathrm{~m} / \mathrm{s}\right)$ in karbonatne kamnine kraško-razpoklinske poroznosti z visoko stopnjo zakraselosti. V razred visoke ranljivosti (4) pa se uvrščajo kvartarni vodonosniki z dobro prepustnostjo $\left(5^{*} 10^{-3} \mathrm{~m} / \mathrm{s}>\mathrm{k}>1 * 10^{-5} \mathrm{~m} / \mathrm{s}\right)$, kamnine kraško-razpoklinske poroznosti srednje zakraselosti in kamnine razpoklinske poroznosti srednje prepustnosti. Temeljni hidrogeološki podatki imajo stopnjo natančnosti merila 1:250.000, njihove lastnosti pa izhajajo iz posameznih litotipnih skupin. Da bi se približali verodostojni predstavitvi ranljivosti podzemnih voda, je bil, poleg že omenjene razvrstitve vodonosnikov, upoštevan še faktor debeline nenasičene cone. Obravnavanim vodonosnikom so pripisane tri stopnje splošne ranljivosti: zmerna splošna ranljivost, visoka splošna ranljivost in zelo visoka splošna ranljivost. Oceno zelo visoke splošne ranljivosti vodonosnikov so dobili naslednji vodonosniki: Prekmursko polje (v geografski literaturi Ravensko in Dolinsko), Mursko in Krško polje, Dolina Bolske in Spodnja Savinjska dolina (Savinjska ravan).

Ocena obremenitev temelji na izpostavljenosti vodonosnikov točkovnim, linijskim in razpršenim virom onesnaževanja, ob upoštevanju regionalnega vodooskrbnega pomena območij podtalnice. Upoštevani so čezmerni onesnaževalci, odlagališča odpadkov, poselitev, kmetijstvo in promet ter regionalni vodooskrbni pomen območij podtalnic. Slednji je bil opredeljen na osnovi ocenjene vrednosti števila prebivalstva, ki se iz določenega vira oskrbuje. Na podlagi skupnih obremenitev so bile podzemne vode razdeljene $\mathrm{v}$ naslednje razrede: zelo majhne obremenitve, majhne obremenitve, zmerne obremenitve, velike obremenitve in zelo velike obremenitve. Med vodonosnike z oceno zelo visokih obremenitev so se uvrstili: Spodnja Savinjska dolina, Dolina Kamniške Bistrice (Kamniškobistriška ravan) in Ljubljansko polje.

$\mathrm{Na}$ osnovi rezultatov državnega monitoringa kakovosti podtalnice in monitoringa podtalnice na območju Mestne občine Ljubljana je bila določena ocena obremenjenosti aluvialnih vodonosnikov. Rezultati so bili obdelani skladno z zahtevami Uredbe o kakovosti podzemnih voda. Kriterija za določi- 
tev čezmerne obremenjenosti po Uredbi sta, da eden od parametrov kemijskega stanja presega določeno mejno vrednost (za nitrate velja dvakratno preseganje mejne vrednosti - $50 \mathrm{mg} \mathrm{NO} /$ /l) oziroma, da trije parametri kemijskega stanja kažejo trend naraščanja.

Pri določevanju obremenjenosti so bili za parametre kemijskega stanja najprej določeni trendi za obdobje 1993-2000 za vse aluvialne vodonosnike in dodatno za vsa merilna mesta mreže monitoringa. Analiza trendov je pokazala, da se v podzemnih vodah vsebnosti nitratov in pesticidov, z izjemo metolaklora, od leta 1993 znižujejo. Kljub temu so povprečne vsebnosti nitratov še vedno višje od mejne vrednosti $25 \mathrm{mg} \mathrm{NO} / 1$ na 12 območjih podtalnice, izjema je le Ljubljansko polje. Skoraj na vseh območjih so presežene tudi mejne vrednosti ortofosfatov in kalija. Med pesticidi sta $\mathrm{v}$ podzemnih vodah najbolj pogosta in z najvišjimi koncentracijami zastopana atrazin in njegov metabolit desetil-atrazin. Njune mejne vrednosti so bile $\mathrm{z}$ izjemo Krškega in Brežiškega polja ter Soške doline (Goriška ravan) presežene na vseh drugih območjih podtalnice. Koncentracija metolaklora se od leta 1995 povečuje predvsem na Ptujskem in Sorškem polju, mejna vrednost pa je bila presežena še na Prekmurskem, Dravskem in Kranjskem polju, v Dolini Bolske ter Spodnji Savinjski dolini.

V študiji se je ugotavljala tudi ustreznost kakovosti podzemne vode glede na mejne vrednosti parametrov kemijskega stanja, navedene v Uredbi o kakovosti podzemnih voda (Uradni list RS, 11/2002). Rezultati so pokazali, da na 5 območjih podtalnice (Spodnja Savinjska dolina, Dolina Bolske, Dravsko, Ptujsko in Prekmursko polje) od 7 do 12 parametrov presega navedene mejne vrednosti. Presežki so ponekod zelo visoki; izstopajo pri metolakloru na Sorškem (8-kratno preseganje) in Ptujskem polju (22-kratno preseganje) ter pri tetrakloroetenu na Prekmurskem polju (92-kratno preseganje).

Čezmerna obremenjenost je bila ocenjena s pomočjo določitve kemijskega stanja podzemne vode in ugotovljenih trendov. Po omenjenih kriterijih je bilo za vseh 13 vodonosnikov ugotovljeno, da so bili v letu 2000 čezmerno obremenjeni. Ker se čezmerna obremenjenost posameznih vodonosnikov močno razlikuje, je bila izvedena podrobnejša členitev. Pri malo čezmerno obremenjenem vodonosniku zgornja meja aritmetičnega povprečja $\left(\mathrm{CL}_{\mathrm{AM}}\right.$, confidence limit anual mean) parametra presega mejno vrednost ali dvojno mejno vrednost za nitrate pri največ 2 parametrih kemijskega stanja (na primer za atrazin in prometrin), pri zmerno čezmerno obremenjenem vodonosniku jo presega pri največ 5 parametrih, pri močno čezmerno obremenjenem pri največ 8 parametrih in pri zelo močno čezmerno obremenjenem pri več kot 8 parametrih kemijskega stanja. Pri določanju stopnje čezmerne obremenjenosti je bil upoštevan tudi faktor preseganja. Ocena čezmerne obremenjenosti se je 
pri faktorju, ki je bil večji od 10, poslabšala za eno stopnjo, razen če je bilo onesnaženje lokalno omejeno.

Primerjava območij 1. kategorije kmetijskih zemljišč z območji pomembnejših podtalnic je pokazala njihovo sovpadanje. Najintenzivnejša pridelava koruze, pšenice, sladkorne pese in hmelja je ravno na območju vodonosnikov, ki imajo zelo visoko ali visoko oceno splošne ranljivosti. Posledica tega je čezmerna obremenjenost vseh 13-tih obravnavanih vodonosnikov, večinoma s snovmi, ki izvirajo iz kmetijske dejavnosti.

Tabela 1: Ocena stopnje čezmerne obremenjenosti s prikazom faktorja preseganja (razmerje med $C L_{A M}$ in mejno vrednostjo)

\begin{tabular}{|l|c|c|c|l|}
\hline Vodonosnik & $\mathbf{n}$ & $\begin{array}{c}\text { Trend } \\
\text { rasti }\end{array}$ & $\mathbf{f}$ (max.) & $\begin{array}{l}\text { Stopnja čezmerne } \\
\text { obremenjenosti }\end{array}$ \\
\hline Prekmursko polje & $\mathbf{1 2}$ & 0 & $\mathbf{9 2 , 5}$ & ZELO MOČNO \\
\hline Mursko polje & 5 & 0 & 6,1 & ZMERNO \\
\hline Dravsko polje & $\mathbf{9}$ & 0 & 6,2 & ZELO MOČNO \\
\hline Ptujsko polje & $\mathbf{7}$ & 0 & $\mathbf{2 1 , 7}$ & ZELO MOČNO \\
\hline Dolina Bolske & 8 & 0 & 6,2 & MOČNO \\
\hline Spodnja Savinjska dolina & 7 & 0 & 3,6 & MOČNO \\
\hline Sorško polje & 4 & 2 & $\mathbf{8 , 5}$ & ZMERNO \\
\hline Kranjsko polje & 3 & 0 & 1,2 & ZMERNO \\
\hline Dolina Kamniške Bistrice & 3 & 0 & 4,0 & ZMERNO \\
\hline Ljubljansko polje & 2 & 2 & 1,1 & MALO \\
\hline Krško polje & 1 & 0 & 1,5 & MALO \\
\hline Brežiško polje & 1 & 0 & 1,4 & MALO \\
\hline Soška dolina & 3 & 0 & 1,4 & ZMERNO \\
\hline
\end{tabular}

Vir: Strokovne podlage za razglasitev ogroženosti podzemne vode v Republiki Sloveniji, MOP, ARSO, Ljubljana 2002.

Ob upoštevanju ocene splošne ranljivosti, ocene obremenitev in ocene čezmerne obremenjenosti je bila za leto 2000 določena ocena ogroženosti 13 vodonosnikov. S primerjanjem in razvrščanjem so bili obravnavani aluvialni vodonosniki razvrščeni v tri razrede ogroženosti:

Najvišjo oceno, zelo visoka ogroženost, so dobila naslednja območja:

Prekmursko polje (Ravensko in Dolinsko) ima zelo visoko oceno splošne ranljivosti, majhno oceno obremenitev in zelo močno čezmerno obremenjenost; $\mathrm{k}$ obremenitvam največ prispevata kmetijstvo in predelovalna dejavnost (klavnica); 12 parametrov presega mejne vrednosti, najvišji faktor preseganja ima tetrakloroeten $(92,6)$;

Ptujsko polje ima visoko oceno splošne ranljivosti, zmerno oceno obremenitev in zelo močno čezmerno obremenjenost; $k$ obremenitvam največ prispe- 
va kmetijstvo; 7 parametrov presega mejno vrednost; najvišji faktor preseganja ima metolaklor $(21,7)$;

Dravsko polje, ki ima visoko oceno splošne ranljivosti, visoko oceno obremenitev in zelo močno čezmerno obremenjenost; $\mathrm{k}$ obremenitvam največ prispevajo komunalne in industrijske odplake ter kmetijstvo; 9 parametrov presega mejne vrednosti, najvišji faktor preseganja ima prometrin $(6,2)$;

Spodnja Savinjska dolina (Savinjska ravan) ima zelo visoko oceno splošne ranljivosti, zelo visoko oceno obremenitev in močno čezmerno obremenjenost; $\mathrm{k}$ obremenitvam največ prispeva kmetijstvo; 7 parametrov presega mejne vrednosti, najvišji faktor preseganja ima atrazin $(3,6)$;

Dolina Bolske ima zelo visoko oceno splošne ranljivosti, zmerno oceno obremenitev in močno čezmerno obremenjenost; k obremenitvam največ prispeva kmetijstvo; 8 parametrov presega mejne vrednosti, najvišji faktor preseganja ima desetil-atrazin $(6,2)$;

Vsa druga območja so dobila oceno visoke (Mursko, Sorško, Krško in Ljubljansko polje ter Soška dolina) in zmerne ogroženosti (Kranjsko in Brežiško polje).

\section{LJUBLJANA KOT PRIMER KRIŽANJA INTERESOV NA PODROČJU VIRI PITNE VODE - KMETIJSTVO}

Bogate zaloge podtalnice $\mathrm{v}$ neposredni bližini in celo pod precejšnjim delom Ljubljane, ocenjene na 100 milijonov $\mathrm{m}^{3}$, oziroma dinamične zaloge na $2 \mathrm{~m}^{3} / \mathrm{sek}$, predstavljajo naravni vir regionalnega pomena (Brečko Grubar, Kušar, Plut, 2000). Najpomembnejši vir pitne vode za oskrbo Ljubljane je podtalnica Ljubljanskega polja, ki zagotavlja 90 \% potrebne količine; pridobivajo jo v črpališčih Kleče, Šentvid, Hrastje in Jarški prod. Z Odlokom o varstvu virov pitne vode (Ur. 1. SRS, 13/1988) je varovalno območje razdeljeno na tri vodovarstvene pasove.

Ljubljansko polje je sorazmerno globok vodonosnik z zelo visoko oceno splošne ranljivosti. Glavni dejavniki ogrožanja podtalnice so neprimerni posegi v okolje (regulacije, melioracije), preveliko izkoriščanje vodnega vira in onesnaževanje okolja. Neprimerni posegi in izkoriščanje vplivajo predvsem na količino podtalnice, emisije snovi v okolje pa na njeno kakovost (Brečko Grubar, 1999).

Glavni povzročitelji onesnaženja so nezajete odpadne vode iz industrije in obrti, izlitja ob neustrezni uporabi, prevozu in skladiščenju podtalnici nevarnih snovi, izcedne vode iz deponij odpadkov in kmetijstvo. Poleg uporabe fitofarmacevtskih sredstev je za kakovost vode problematično predvsem gnojenje. Izpiranje neizrabljenega dušika v podtalnico zaradi presežka gnojil ali ča- 
sovno neustreznega gnojenja povzroča povečane koncentracije nitratov in nitritov, gnojenje z organskimi gnojili pa tudi bakteriološko onesnaženje.

Večina kmetov na Ljubljanskem polju se ukvarja s tradicionalno hlevsko živinorejo. Značilna je prevlada govedoreje, precej manjša je vloga konjereje in prašičereje. Med 155 evidentiranimi hlevi jih je kar 134 ali 86,5 opremljenih z ločenim zbiranjem gnoja z nastiljem in gnojnico (Kladnik, Smrekar, 2002). Med njimi jih je skoraj polovica $\mathrm{v}$ drugem vodovarstvenem pasu, od tega 49 na vodovarstvenem območju Hrastje, kar ni ugodno zaradi njegove dolvodne lege ob sorazmerno majhni globini do gladine podtalnice. Za sodobnejši način kmetovanja velja zbiranje živinskih gnojil z gnojevko, kar se pojavlja na 21 kmetijah.

$\mathrm{Na}$ vseh kmetijah je bilo registriranih skupno 307 gnojnih objektov, od tega 151 gnojišč in 156 gnojnih jam (ibid.). Njihovo urejenost smo ugotavljali $\mathrm{s}$ pomočjo ankete na kmetijah, ki je vsebovala vprašanja o vodoprepustnosti, morebitnem obodu in urejenosti iztoka. Rezultati analize kažejo, da je kar 110 $(72,8 \%)$ gnojišč urejenih, največ takšnih $(86,4 \%)$ je na območju Hrastja v drugem vodovarstvenem pasu. Ker je povprečna starost objekta kar 37 let, 25 jih je bilo urejenih celo pred drugo svetovno vojno, se pojavlja dvom o njihovi dejanski ustreznosti. Delno urejenih je $18(11,9 \%)$ gnojišč, neurejenih pa 23 $(15,2 \%)$.

Posebno pozornost vzbuja 9 najbolj neurejenih gnojišč, ki nimajo niti betoniranega dna niti oboda, tako da gnojnica pronica neposredno v prst in naprej v podtalnico. V takšnih primerih gre za izrazito točkovno obremenjevanje okolja. Praviloma gre za manjše kmetije s povprečno 4 glavami velike živine (GVŽ); v enem primeru vrednost doseže celo $12 \mathrm{GVŽ.}$

Popisni podatki o urejenosti gnojnih jam še bolj presenečajo, saj jih je kar $77,6 \%$ urejenih in samo 8 (5,2 \%) naj bi jih bilo vodoprepustnih. Tudi v tem primeru starostna struktura objektov napeljuje k realnejši oceni, saj je njihova povprečna starost 36 let, pred drugo svetovno vojno pa je bilo zgrajenih kar 27 objektov, najstarejši že leta 1900.

$Z$ vidika ustreznega ravnanja $\mathrm{z}$ živinskimi gnojili je zelo pomembna velikost gnojišč in gnojnih jam. Za skladiščenje organskih gnojil je namreč potrebno zagotoviti ustrezno velik prostor, ki mora zadoščati za premostitev obdobij, ko je po Uredbi o vnosu nevarnih snovi in rastlinskih gnojil v tla (Ur.l., 68/1996) prepovedano ali onemogočeno odlaganje na kmetijska zemljišča. Za $1 \mathrm{GVŽ} \mathrm{je} \mathrm{potrebno} \mathrm{zagotoviti} \mathrm{najmanj} 2 \mathrm{~m}^{2}$ veliko ploskev za skladiščenje hlevskega gnoja, jamo prostornine $3,5 \mathrm{~m}^{3}$ za gnojnico oziroma $8 \mathrm{~m}^{3}$ za skladiščenje gnojevke (Dobra kmetijska praksa pri gnojenju, 2000). Med vsemi gnojnimi objekti jih imata primerno kapaciteto skoraj dve tretjini. Na območju Hrastja v drugem vodovarstvenem pasu je kar 31 (10,1\%) gnojišč oziroma gnojnih jam s premajhno kapaciteto. Le izjemoma so gnojni objekti pokriti, 
tako da je ob povprečju skoraj $1400 \mathrm{~mm}$ padavin $/ \mathrm{m}^{2}$ že tako premajhna zmogljivost še bolj izrazita.

10 kmetovalcev (6,5 \%) priznava, da zavestno kršijo prepoved vnosa živinskih gnojil na obdelovalna zemljišča, ker nimajo dovolj velikih gnojnih objektov, ki bi omogočali hranjenje gnoja, gnojnice in gnojevke v času prepovedanega vnosa.

Ob očitno slabšem stanju gnojnih objektov na vodovarstvenem območju Ljubljanskega polja, kot smo jih lahko ugotovili ob analizi mnenj popisanih kmetovalcev, se zastavlja vprašanje, koliko kmetov in pod kakšnimi pogoji je pripravljenih obnavljati hleve s pripadajočimi objekti z namenom zmanjšanja obremenjevanja podtalnice. Kakršnokoli posodabljanje objektov zavračajo na kar 90 kmetijah (58,1\%). Malo manj kot četrtina kmetovalcev je pripravljena na posodobitve, polovica od teh izključno ob nepovratnih sredstvih, preostala polovica pa tudi z lastno udeležbo.

Zelo zanimivo je mnenje popisanih kmetov o vplivu njihovih gnojnih objektov na okolje. Le 21 oziroma 13,5 \% jih priznava kakršenkoli vpliv. Med njimi jih je še največ (15) takšnih, ki se jim zdi najbolj obremenjujoč smrad, po mnenju treh gnojni objekti onesnažujejo površinsko vodo, samo eden pa meni, da odplake iz njegovega gnojnega objekta onesnažujejo podtalnico. Kar 113 kmetov oziroma $72,9 \%$ se je izreklo, da njihovi gnojni objekti nimajo nikakršnega vpliva na okolje oziroma pokrajino.

Kot je pokazala druga raziskava (Kladnik, 2002), ne moremo biti zadovoljni niti z gnojilno prakso kmetovalcev, saj njihova ozaveščenost o potrebnem natančnem odmerjanju gnojil še ni zadovoljiva. Menijo, da se bo količina pridelkov zmanjšala, če ne bodo obilno gnojili, zato se pogosto odločajo po načelu "vsakega po malo ne more škoditi". Njihovo odločanje o gnojenju praviloma temelji na izkušnjah, bistveno manj pa na analizah prsti in pridelkov, pomembnih tudi za primeren izbor kultur in uporabo primernih pridelovalnih tehnik. Praksa analiziranja prsti na anketiranih kmetijah ni razveseljiva. To velja za vse majhne kmetije, kjer analiz prsti niso še nikoli opravili. S povečevanjem posesti se stanje izboljšuje, tako da je precej obratov, na katerih opravljajo analize redko oziroma občasno, na dveh kmetijah v velikostni skupini od 10 do 20 ha so se pohvalili celo $\mathrm{z}$ rednim tovrstnim nadzorom.

Mnenje o vplivih agrokemičnih sredstev na okolje razkriva, da anketirance najbolj skrbi škodljiv vpliv na kakovost kmetijskih pridelkov, le malo redkeje se pojavlja trditev o škodljivosti za kakovost podtalnice. Vse druge navedbe, negativen vpliv na živalski svet, kakovost prsti, kakovost hrane in kakovost tekočih voda, so bistveno redkejše (ibid.).

$\mathrm{Na}$ območju znotraj ljubljanskega avtocestnega obroča je bilo z digitalizacijo evidentiranih 744 ha obdelovalnih zemljišč, kar je komaj 13,4 \% od celotne površine preučevanega območja. Prostorska zasnova mesta predvideva, da 
bodo obsežna območja prepuščena nekmetijski rabi (Prostorski plan MOL, 2001). Za intenzivno kmetijsko rabo naj bi se ohranjala najustreznejša kmetijska zemljišča, pri čemer so ob njihovi kakovosti upoštevane tudi velikost in zaokroženost območij ter lokacija znotraj mesta. Tako naj bi v kmetijski rabi ostalo vsega 204 ha kmetijskih zemljišč, kar pomeni komaj 3,7 \% površine znotraj obroča oziroma $27,4 \%$ od zdajšnje površine kmetijskih zemljišč. Izoblikovalo se bo le pet zaokroženih območij kmetijskih zemljišč. Pred spremembo namembnosti so varovani zlasti kompleksi kmetijskih zemljišč nad prodnimi vodonosniki.

Predvidoma bo še vedno imelo pomembno vlogo vrtičkarstvo, ljubiteljsko vrtnarstvo, ki je v razvitem delu sveta razširjeno zlasti na obrobjih večjih mest, praviloma na za to posebej odrejenih in urejenih območjih. Tako naj bi bilo tudi pri nas, praksa v Ljubljani pa kaže, da gre v bistvu za enega od najbolj stihijskih porabnikov dragocenega mestnega prostora (Kladnik, 2002). Pojavlja se ob ograjah poslovnih območij, na nasipih železniških prog, obrežjih vodotokov, ostankih neizkoriščenih gradbenih parcel, med njivami in travniki, na robu gozda in pred stanovanjskimi bloki. $Z$ vrtički so preprežena območja, ki so ostala neizkoriščena po gradnji, ki so dolgoročno predvidena za gradnjo in nekatera kmetijska območja, na katerih je upadel interes za kmetijstvo. Primerno urejena so le redka, načrtno zasnovana območja (na primer pri Litostroju), že dolgo namenjena tovrstni rabi.

Leta 2000 so vrtički znotraj avtocestnega obroča zasedali 86,3 ha zemljišč ali 1,6 \% od celotne površine območja (ibid.). Glavni problemi, povezani z vrtičkarstvom, so (Simoneti in dr., 1997):

- negativni vplivi na okolje zaradi nestrokovne pridelave brez nadzora;

- zasedanje okoljevarstveno problematičnih zemljišč (ožji vodovarstveni pasovi, pasovi ob cestah, železnicah in vodotokih, onesnažena zemljišča, bližina visokonapetostnih vodov);

- nekontrolirano postavljanje raznovrstnih objektov na vrtičkih (za hrambo orodja, zavetje, tudi za začasno bivanje);

- komunalna neurejenost (brez odvoza odpadkov, sanitarij ter vode za pitje in zalivanje);

- kopičenje odsluženih, malo uporabnih kosov pohištva in (nevarnih) snovi v zasilnih objektih;

- nekontroliran dostop avtomobilov;

- neurejen, ponekod celo zanemarjen videz.

Čeprav je vloga vrtičkarstva v pridelavi hrane majhna, je dejavnost z zornega kota varovanja okolja kmetijstvo v malem, saj vrtičkarji prav tako uporabljajo gnojila in sredstva za varstvo rastlin. V primerjavi s kmeti so vrtičkarji pri njihovi uporabi manj zmerni; večina jih je o pridelavi vrtnin le laično poučena. Mnogi med njimi se s kemičnimi pripravki lotevajo tako rekoč vsake rastline 
posebej, pri čemer jih vodi želja po obilnem in privlačnem pridelku, medtem ko je gospodarnost pridelave potisnjena v ozadje. Nasprotno se nekateri v želji po neoporečnem pridelku odpovedo vsakršni rabi mineralnih gnojil in fitofarmacevtskih sredstev.

Ker je nadzor nad uporabo gnojil in zaščitnih sredstev na vrtičkih praktično nemogoč, je povsem na mestu prizadevanje, da naj na vodovarstvenem območju ne bi bilo vrtičkov. Zdaj so ponekod celo neposredno ob meji najstrožje varovanega prvega vodovarstvenega pasu. $Z$ vidika varovanja podtalnice je zanimivo tudi obdelovanje vrtov in vzdrževanje zelenic okrog individualnih hiš. Tudi tu se uporabljajo fitofarmacevtska sredstva, vendar je tovrstna problematika še docela neraziskana.

$\mathrm{V}$ nasprotju s prevladujočim razpršenim kmetijskim obremenjevanjem okolja, gre v primeru rastlinjakov za točkovne obremenitve. Sicer rastlinjaki veljajo za sodobno in neobhodno potrebno kmetijsko tehnologijo. Tudi pri tovrstni pridelavi je zaskrbljujoča pretirana uporaba sredstev za varstvo rastlin in mineralnih gnojil, kar je potrdila opravljena študija (Kladnik, Rejec Brancelj, 2000).

Rastlinjake anketirani kmetovalci večinoma gnojijo kombinirano, $\mathrm{z}$ organskimi in mineralnimi gnojili. Dobro desetino jih gnojijo samo z organskimi gnojili, zlasti tiste, namenjene pridelavi zelenjave. Tretjino rastlinjakov se gnoji izključno $\mathrm{z}$ mineralnimi gnojili. Intenzivnost pridelave $\mathrm{v}$ rastlinjakih odražajo tudi poraba mineralnih gnojil, fitofarmacevtskih sredstev in energetska intenzivnost (tabela 2).

Tabela 2: Primerjava nekaterih parametrov intenzivnosti kmetovanja $v$ rastlinjakih, na ravninah Slovenije in Sloveniji kot celoti

\begin{tabular}{|l|r|r|r|}
\hline & rastlinjaki & \multicolumn{1}{c|}{ ravnine } & Slovenija \\
\hline energetska intenzivnost & $55,0 \mathrm{GJ} / \mathrm{ha}$ & $35,6 \mathrm{GJ} / \mathrm{ha}$ & $30,5 \mathrm{GJ} / \mathrm{ha}$ \\
\hline poraba organskih gnojil & $54 \mathrm{~m}^{3} / \mathrm{ha}$ & $23 \mathrm{~m}^{3} / \mathrm{ha}$ & $15 \mathrm{~m}^{3} / \mathrm{ha}$ \\
\hline poraba mineralnih gnojil & $1842 \mathrm{~kg} / \mathrm{ha}$ & $439 \mathrm{~kg} / \mathrm{ha}$ & $311 \mathrm{~kg} / \mathrm{ha}$ \\
\hline poraba sredstev za varstvo rastlin & $3,2 \mathrm{~kg} / \mathrm{ha}$ & $2 \mathrm{~kg} / \mathrm{ha}$ & $3,6 \mathrm{~kg} / \mathrm{ha}$ \\
\hline
\end{tabular}

Vira: Rejec Brancelj, I., Okoljski učinki intenzivnega kmetovanja v rastlinjakih, 2000. Rejec Brancelj, I., Kmetijsko obremenjevanje okolja v Sloveniji, 2001.

Preučene kmetije s pridelavo $\mathrm{v}$ rastlinjakih se po energetskih in snovnih vnosih uvrščajo med najbolj intenzivne v slovenskem merilu. Na več kot tretjini kmetij nameravajo $\mathrm{v}$ naslednjih letih postaviti nove rastlinjake, ki bi jih bilo potrebno usmerjati zunaj vodovarstvenega območja in za pridelavo v njih zahtevati primerno izobrazbeno raven ter knjigovodstvo, ki bo upoštevalo tudi ustrezno količino analiz, tako prsti kot pridelkov. 


\section{Viri in literatura:}

Brečko Grubar, V., 1998. Pokrajinska občutljivost območij podtalnic v Sloveniji z vidika kmetijstva. V: Kmetijstvo in okolje. Kmetijski inštitut, Ljubljana, 49-55.

Brečko Grubar, V., 1999. Pokrajinska ranljivost najpomembnejšega vodnega vira Ljubljane. V: Geografski zbornik, 39, Geografski inštitut Antona Melika ZRC SAZU, Ljubljana, 51-97.

Dobra kmetijska praksa pri gnojenju. Ministrstvo za kmetijstvo, gozdarstvo in prehrano, Ministrstvo za okolje in prostor. Ljubljana, 2002.

Kladnik, D., 2000. Uveljavljanje intenzivnega pridelovanja v rastlinjakih. V: Ljubljana - Geografija mesta. Ljubljansko geografsko društvo, Založba ZRC, Ljubljana, 215-228.

Kladnik, D., 2002. Pomen in perspektive zasebnega kmetijstva znotraj strnjeno pozidanih delov Ljubljane. Inštitut za geografijo, Ljubljana, 17-36.

Kladnik, D., Rejec Brancelj, I., 2000. Prostorski, okoljski, socialni in gospodarski učinki intenzivnega kmetovanja v rastlinjakih. Inštitut za geografijo, Ljubljana, 92-107.

Kladnik, D., Smrekar, A., 2002. Kmetijstvo na vodovarstvenih območjih s poudarkom na popisu gnojišč in gnojnih jam. Geografski inštitut Antona Melika Znanstvenoraziskovalnega centra Slovenske akademije znanosti in umetnosti, Ljubljana.

Kranjc, S. in sod, 1995, Bilanca podzemnih voda RS Slovenije. Inštitut za geologijo, geotehniko in geofiziko, Ljubljana.

Leskošek, M., 1998. Prispevek k gnojenju v slovenskih vodovarstvenih območjih. V: Kmetijstvo in okolje. Kmetijski inštitut, Ljubljana, 131-138.

Maslo, G., 2002. Kmetijstvo na zavarovanih pasovih pitne vode. V: Ljubljana, Glasilo Mestne občine Ljubljana. Ljubljana, 39-40.

Odlok o območjih vodonosnikov in njihovih hidrografskih zaledij, ogroženih zaradi fitofarmacevtskih sredstev. Uradni list RS, 97/2002. Ljubljana, 2002 .

Odlok o varstvu virov pitne vode. Uradni list Socialistične republike Slovenije 13/1988, Ljubljana, 1988.

Prostorski plan Mestne občine Ljubljana, Prostorska zasnova. Oddelek za urbanizem Mestne občine Ljubljana, 2002.

Rejec Brancelj, I., 2000. Okoljski učinki intenzivnega kmetovanja v rastlinjakih. V: Ljubljana - Geografija mesta. Ljubljansko geografsko društvo, Založba ZRC, Ljubljana, 185-193.

Rejec Brancelj, I., 2001: Kmetijsko obremenjevanje okolja v Sloveniji. Inštitut za geografijo, Ljubljana, 104 str. 
Rejec Brancelj, I. in sod., 2002. Strokovne podlage za razglasitev ogroženosti podzemne vode v Republiki Sloveniji, Projektna naloga. Ministrstvo za okolje, prostor in energijo, Agencija Republike Slovenije za okolje, Ljubljana.

Simoneti, M., Bevk, J., Pintar, M., Zupan, M., Gajšek, P., Golobič, M., Pleško, R., Bevk, M., 1997. Usmeritve in pogoji za nadaljnji razvoj vrtičkarstva v Ljubljani. Ljubljanski urbanistični zavod, Ljubljana.

Uredba o določanju statusa zaradi fitofarmacevtskih sredstev ogroženega območja vodonosnikov in njihovih hidrografskih zaledij in o ukrepih celovite sanacije. Uradni list RS, 97/2002. Ljubljana, 2002.

Uredba o kakovosti podzemne vode. Uradni list RS, 11/2002. Ljubljana, 2002. Uredba o vnosu nevarnih snovi in rastlinskih hranil v tla. Uradni list RS, 68/1996 in 35/2001, Ljubljana, 1996, 2001.

Usmerjanje kmetijstva na vodovarstvenih območjih Mestne občine Ljubljana. Kmetijski inštitut Slovenije, Ljubljana, 2002.

\section{INTEGRAL BURDENING OF GRAVEL PLAINS IN SLOVENIA}

\section{Summary}

In Slovenia, groundwater is the most important source of drinking water, supplying more than $90 \%$ of the entire population. In some alluvial aquifers, considerably increased contents of phytopharmaceutical elements, nitrates, and halogenous organic compounds have been found. Due to the poorer self-cleaning capability of alluvial plains, the groundwater here is becoming increasingly burdened.

The integral burdening of the gravel plains in Slovenia is the result of various interrelated activities in these areas, and its study therefore demands an integrated approach and the urgent protection of the groundwater quality, which is anticipated by the Uredba o kakovosti podzemne vode (Ur. 1. RS, 11/2002) ("Decree on the Quality of Groundwater").

Areas of alluvial aquifers in Slovenia are threatened as the consequence of the natural vulnerability of aquifers, great burdening, and the poor quality of the groundwater. On considering the assessment of general vulnerability, the assessment of burdening, and the assessment of excessive burdening, our assessment of the threat to aquifers according to the standards set by the Uredba for the year 2000 revealed that all thirteen aquifers are threatened. 
The highest level of threat is characteristic for the following areas: Prekmursko polje (Ravensko polje in Dolinsko polje), Dravsko polje, Ptujsko polje, the Lower Savinja Valley, and the Bolska Valley. A high level of threat appears for Mursko polje, Sorško polje, Krško polje, and Ljubljansko polje.

Stockbreeding presents both a point and dispersed source of burdening. In water protection areas containing sources of drinking water (Ur. 1. SRS, 13/1988) in Ljubljansko polje, a list of dunghills and dung pits was compiled. 307 objects were recorded, 152 of which overlapped second protection area. According to the available data, there are fifty-six partially or completely unregulated dunghills and dung pits (eighteen overlapping second protection area).

Point sources of pollution also include gardens and greenhouses. With such production we find negative influences on the environment due to unprofessional production without supervision, and communal regulation is lacking as well. As a rule, the application of fertilizers is excessive, a statement supported by the fact that the average use of mineral fertilizers in greenhouses in the Ljubljana area is $1,842 \mathrm{~kg}$ per hectare of farming land while the average use on alluvial plains is $439 \mathrm{~kg}$ and in Slovenia as a whole, $311 \mathrm{~kg}$. 